\title{
The Present State of the Croatian Public Debt
}

\section{Bubaš, Zoran}

Source / Izvornik: Occasional Paper Series, 1998, 2, 1 - 17

Journal article, Published version

Rad u časopisu, Objavljena verzija rada (izdavačev PDF)

https://doi.org/10.3326/ops.6

Permanent link / Trajna poveznica: https://urn.nsk.hr/urn:nbn:hr:242:734687

Rights / Prava: Attribution-NonCommercial-NoDerivatives 4.0 International/ImenovanjeNekomercijalno-Bez prerada 4.0 međunarodna

Download date / Datum preuzimanja: 2023-04-26

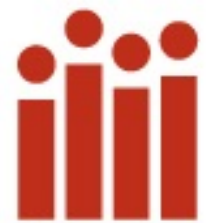




\title{
THE PRESENT STATE OF THE CROATIAN PUBLIC DEBT
}

\author{
Zoran Bubaš \\ Occasional Paper No. 6 \\ December 1998
}

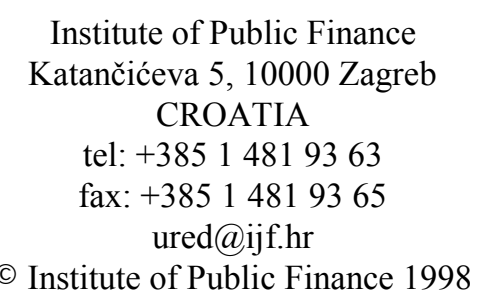




\title{
THE PRESENT STATE OF THE CROATIAN PUBLIC DEBT
}

\author{
Zoran Bubaš
}

\section{ABSTRACT}

The statistics of the public debt of the Republic of Croatia show that in spite of considerable positive advances in the statistical purview of the public sector, the purview of the public debt is not complete even in the narrowest understanding of the concept of public debt. For this reason it is necessary precisely to determine what should be a part of the public debt, and separate the internal from the external public debt. Available data about the state of the total public debt confirm the thesis that the Croatian public debt in 1997 was of moderate size (about $33 \%$ of GDP) but show that its structure is changing: the reduction of the internal debt is accompanied by a rise in the external indebtedness of the public sector.

Because of the general economic situation, the open savings-investment gap and debt inherited from the former state of Yugoslavia there are many challenges before public debt policy. Since most of the new net borrowings abroad in 1997 were accounted for by public and publicly guaranteed debt, the decision makers have to pay particular attention to the proper use of the funds borrowed and to a cautious approach to the issue of state guarantees. Bearing in mind the possibility of refinancing the debt, a small and open country like Croatia cannot be compared with highly developed countries the debts of which are always refinanced and in fact never fall due for payment. For Croatia, glitches in the world capital markets could have very serious consequences, and it is necessary to be prepared for future challenges as soon as possible. 


\section{THE PRESENT STATE OF THE CROATIAN PUBLIC DEBT}

\section{Introduction}

Most experts agree that the total public debt of the Republic of Croatia at this moment is of moderate size. At the moment it is not possible to foresee how the stock and structure of the total public debt will change, and whether the burden of it will grow in time. The reason for this is to be found not only in the uncertainty and challenges brought by the future, but partially in the fact that there is a certain methodological problem connected with the concept of the public debt.

This work constitutes a picture, that is the state and structure of the internal and external public debt of the Republic of Croatia. During evaluation of the total public debt of the Republic of Croatia, questions of the scope of the public debt were dealt with, as well as ways of financing the surplus of investment over domestic saving. As well as the need for and the manner of solving the problem of the correct purview of the state of the total public debt, in the closing section methodological (to do with classification) lack of adjustment with respect to the structure of the public (external and internal) debt is pointed to. In the light of the current economic situation and the open gap between savings and investment, the importance of a cautious and carefully thought out approach to public borrowing is stressed, especially of borrowing abroad, and of the effective use of funds that are borrowed.

A public debt can be defined as the accumulated borrowed monetary resources of the state, or the sum of all claims that creditors have against the state at a given moment. It is a matter, de facto, of the accumulated budgetary deficits that the state has financed via borrowing. Depending on whether the state owes creditors at home or abroad, we can distinguish between internal and external public debt.

For the financing of public sector deficits, in practice the phrases national debt and public debt are often used as synonyms, occasionally public borrowing as well. However, there is a need for a certain conceptual delimitation. The question of the possible identity of national and public debt comes up while one is looking at the external and internal components of the public sector debt. If it is a matter of internal public debt, or state borrowing, this could really be a matter of synonyms. However, if borrowing abroad is considered, such a standpoint is not a priori logical. In such a case it can be said that the foreign debt of the state represents a wider concept, which, apart from the debts of the public sector also includes the debts of the other economic sectors (households, banks, companies). For this reason, if one starts from the equivalence of public and national debt that is usually made, it is necessary, because of the need to avoid methodological problems, conceptually to define the foreign debt of the entire national economy

\footnotetext{
1 This Occasional Paper is the translation of the article written by Zoran Bubaš (Institute of Public Finance, Zagreb). The article was accepted in July 1998, and was published in Croatian in the Institute's journal "Financijska praksa", Volume 22, Number 4-5 (October 1998).
} 
differently. In the older literature in particular, it is possible to find the term public loan used in the sense of public debt. However, public loan is a narrower concept, which represents only one of the ways of financing the public debt, and thus cannot be identified with the public debt.

Since it is difficult unambiguously to define what the public sector in the economy precisely embraces, the same goes for the public debt. The problems that derive from the scope of the public sector being different are particularly important when it comes to international comparisons. What in all countries certainly does come into the public debt is the debts of medium and lower units of the national government. Many countries do not show the debts of public companies, state agencies, social insurance and other "national" funds as a public debt, although their source is in the public sector. The problem of the scope of the public debt is also present in the scope and treatment of state guarantees, which always constitute a potential public debt, and which in some countries are frequently not expressed as part of any existing or potential debt of the state.

\section{The state and structure of the internal public debt}

When one talks of the Croatian public debt, it is necessary to stress that the major part of this public debt does not point to a "normal" need for financing the public sector, since its origin is in the peculiarities of the former political and economic system, and in the breakdown of Yugoslavia. This relates to both the internal and the external public debt.

The internal public debt of the Republic of Croatia came at the end of 1991 to about DM6.58 billion. Of this, over DM5 billion related to the debt on the basis of frozen foreign exchange deposits (FFEDs), which came into being when Croatian citizens' claims against the National Bank of Yugoslavia for foreign currency deposits were transformed into claims against the Republic of Croatia. A further debt of DM1.55 billion ("big bonds") arose through the way corporate debts to the banking sector were settled.

Table 1: Stock of the internal public debt

\begin{tabular}{|l|c|c|c|r|r|r|r|r|}
\hline (end of year) & 1991 & 1992 & 1993 & \multicolumn{1}{|c|}{1994} & \multicolumn{1}{|c|}{1995} & \multicolumn{1}{c|}{1996} & \multicolumn{1}{c|}{1997} \\
\hline & \multicolumn{7}{|c|}{ Internal debt's stock } \\
\hline in mil. DM & 6583.99 & 6282.20 & 5537.41 & 4758.87 & 4426.83 & 4641.43 & 4130.33 \\
in mil. HRK & - & - & - & 17284.70 & 16405.40 & 16533.70 & 14501.60 \\
\hline & \multicolumn{7}{|c|}{ Change } \\
\cline { 2 - 8 } in mil. DM & - & -301.79 & -744.79 & -778.54 & -332.04 & 214.60 & -511.10 \\
in mil. HRK & - & - & - & - & -879.30 & 128.30 & -2032.10 \\
\hline
\end{tabular}

Source: *** (1996); Ministry of Finance (1998b).

2 The public sector is defined relatively precisely and uniformly in the IMF's Government Finance Statistics, which is adjusted with the system of national accounts and other statistics (balance of payments, monetary statistics). Although the public sector in the collection of statistical data is limited to the so called "general government" and does not include public corporations, the beginning of the application of GFS methodology in Croatia was a big advance for the statistical purview of the public sector (see: IMF, 1992). 
Since 1991 there has been a noticeable reduction of the internal debt, attributable above all to the favourable circumstances for using frozen foreign exchange deposits in the process of privatisation. At the end of 1995 the stock of the internal debt came to a bit more than DM4.4 billion, a fall of $32.7 \%$ since the end of 1991. Mostly because of the reconstruction of the Croatian banking system, and also because of the refinancing of current obligations and the beginning of the issue of treasury bills, the situation of the debt at the end of 1996 was $4.8 \%$ up on 1995. If the public debt trends are looked at in terms of kuna, the rise in the internal debt in 1996 is almost negligible.]

Table 2 shows how, where and why the country used the instrument of the public debt.

Table 2: Croatia's internal debt structure

\begin{tabular}{|l|ccccccc|}
\hline (in mil. DM, end of year) & 1991 & 1992 & 1993 & 1994 & 1995 & 1996 & 1997 \\
\hline Long-term debt & & & & & & & \\
FFEDs & 5033.90 & 4563.61 & 3989.68 & 3245.91 & 2796.28 & 2382.75 & 2020.30 \\
Big bonds & 1550.09 & 1597.28 & 1420.03 & 1360.72 & 1301.42 & 1087.37 & 1017.50 \\
Bonds 93 & - & - & 107.37 & 89.48 & 53.69 & 17.90 & - \\
Bonds 94-i & - & & - & 47.61 & - & - & - \\
Bonds 94-II & - & - & - & - & 9.66 & - & - \\
JDA bonds & - & - & - & - & 153.70 & 128.08 & 77.07 \\
JDB bonds & - & - & - & - & - & 147.10 & 98.35 \\
Reconstruction bonds & - & - & 16.25 & 10.87 & 7.96 & 7.32 & 5.50 \\
CNB ${ }^{1)}$ loan I & - & 31.31 & 4.08 & 4.27 & 3.78 & 3.48 & - \\
CNB loan III & - & - & - & - & 100.33 & 54.44 & - \\
Eurokuna bonds & - & - & - & - & - & - & 85.44 \\
Bank reconstruction bonds & - & - & - & - & - & 736.59 & 724.82 \\
\hline Short-term debt & & & & & & & \\
Treasury bills & - & - & - & - & - & 77.25 & 128.05 \\
\hline Internal debt $(\Sigma)$ & 6583.99 & 6282.20 & 5537.41 & 4758.86 & 4426.82 & 4642.28 & 4157.03 \\
\hline
\end{tabular}

Source: *** (1996); Ministry of Finance (1997a), (1997b), (1998a).

Note: ${ }^{1)}$ Croatian National Bank

Since 1991, frozen foreign currency savings have constituted by far the biggest part of the internal debt. While in 1991 FFEDs amounted to $76 \%$ of the total internal debt, at the end of 1997 it came to less than $50 \%$. To pay the interest and principal on the FFEDs, the state issued five more series of bonds, of which Bonds 93, Bonds 94 I and Bonds 94 II served to finance accrued interest on FFEDs during 1993. While these bonds had the same rate of interest, $5 \%$, as the old foreign currency savings, the payment of the first and second annuity was ensured by refinancing at 12\% (JDA bonds) and $8 \%$ (JDB bonds). Although with these bonds the state reserved the possibility of withdrawing the debt by exchanging it for shares and shares in the portfolio of the privatisation and pension funds, this was almost not resorted to. The main reason for this is obviously in the high yield of the bonds, and after they were quoted on the Zagreb Stock Exchange, even foreign investors showed a lot of interest in JDA and JDB bonds.

3 However, since most of the internal debt is denominated in DM, the debt shown in kuna distorts the picture because of changes in the HRK/DM exchange rate. 
During 1991 and 1992 the government, carrying out the quiet reconstruction of the great loss-making corporations and of the banking sector that kept them afloat with loans, issued bonds in the total amount of over DM1.5 billion. These big bonds as they were called replaced claims against the corporations in the balance sheets of the banks, and the state increased its share in the equity of the companies. Big bonds are a specific debt instrument, with features that entirely suit the purpose for which they were issued - the clearing of the balance sheets of debtors and creditors. They were issued for 20 years, with payments in 40 half yearly annuities, and do not attract interest but the nominal value of the debt is revalued according to the Croatian industrial price index. The corporations removed dubious debts from their balance sheets and increased their equity, the banks replaced the dubious loans in their assets by what are by definition safe claims - government bonds.

The three reconstruction bond issues of 1992 and 1993 should be a typical example of structural indebtedness, because they were issued to finance the economic capacities and the parts of the cultural heritage damaged in the war. The issues were primarily directed at the Croatian diaspora, and the bonds were denominated in DM, US\$, Canadian and Australian dollars. The interest was slightly higher than the interest on the government bonds of Germany, Canada, the US and Australia. These bonds also had a number of advantages: from tax relief to the possibility of being used in the process of privatisation.

After the action of clearing the balance sheets of the banks (and corporations) in 1991, which nevertheless left the essence of the problem untouched, the potential losses in the banking system once again threatened to bring about the collapse of the banking system in the course of the next three years\}A more serious approach to the problem of the reconstruction of the banks presumed, among other things, a new bond issue - this time in the pre-reconstruction process. At the end of 1997, the obligations of the state deriving from bonds for the reconstruction of the banks made up almost $20 \%$ of the total long-term internal debt. Theoretically, this debt should be cancelled by the sale of the state's equity in the reconstructed banks, which still has to be confirmed by practice.

In January 1997, Croatia issued its so-called "Eurokuna" bonds in the amount of 300 million kuna, with an interest rate of $12.5 \%$, the whole issue falling due in December 1998. Of this, 150 million kuna worth of bonds were issued on the domestic market, and 150 million on the international capital market. The chief manager of the issue on the international market was Merrill Lynch, and of the national issue Zagrebačka banka. At the same time, in January 1997, credit ratings for the Republic of Croatia were

\footnotetext{
${ }^{4}$ According to the Decree about issuing bonds for the collection of funds for the reconstruction of the Republic of Croatia (Narodne novine (Official Gazette) No. 65/91), the purchaser of bonds could reduce the tax basis by 5\% of the nominal value of the bonds purchased in the year of payment. Private persons were allowed to reduce their income tax base by $10 \%$ of the nominal value of the bonds. The bonds could be used as a means of payment for shares during transformation and privatisation, with a discount of $10 \%$ for Croatian citizens domiciled in Croatia and of $20 \%$ for Croatian citizens domiciled abroad. Since most of these bonds were exchanged for share, the major part of the debt relating to these bonds was settled before it became due.

5 At the end of 1994, the potential losses in the Croatian banking system were estimated at $65 \%$ of total capital (Prskalo, 1994).
} 
published; they had been sought at the end of 1996. Since Croatia got the expected investment credit rating? it is an open question whether the issue of Eurokuna bonds could not have been done on better conditions than were agreed on just before the publication of the credit rating.

Funds borrowed from the central bank are always an interesting component of the borrowings of every country. According to data from the Ministry of Finance of the Republic of Croatia, at the end of 1997 the government returned its borrowings before final maturity. This is to do with 15.5 million kuna borrowed in 1992 and the kuna equivalent of US\$70 million in 1995. The loan of 1992 was supposed to be repaid in 20 half yearly annuities, bearing interest of $1 \%$. The other loan, which the government took on to regulate its obligations to the Paris Club, bore interest of $8.5 \%$ and was supposed to be repaid in eight annuities over two years. Bearing in mind all the dangers attending this kind of financing, the knowledge that loans from the central bank are relatively easily accessible must cause some unease. Short-term loans to the state to bridge the gap between incomings and outgoings are not here being called into question, although this problem obviously can be successfully settled without the direct interference of the central bank.

In mid-1996, the Finance Ministry started off, for this purpose, the practice of issuing treasury bills for maturity periods of 32 and 91 days, and a year later for 182 days. In the period from September 1996 to November 1997, the Finance Ministry held 39 auctions, which were mainly held three times a month. The average amount of an issue came to 81 million kuna. According to the results of the last auction in 1996, the interest rate on 42 day treasury bills was $11 \%$, and on 91 day treasury bills $13 \%$. By October 1997 the interest on 42 day treasury bills had fallen to $8.55 \%$, and on 91 day treasury bills to $9.90 \%$.

A comparison of the interest rates of treasury bills and the central bank bills of the CNB of the same date of payment leads to the conclusion that the interest on treasury bills is converging on that of central bank bills. DThis convergence of the interest rates of old and new money market instruments with the same degree of risk can be understood as a sign of the successful establishment of the model of issuing treasury bills in Croatia.?

\section{The situation and structure of the foreign public debt}

6 Standard and Poor's: BBB-; Moody's Investors Service: Baa3; IBCA: BBB-.

7 In October 199735 day central bank bills had an interest rate of $8 \%$ and 91 day central bank bills a rate of $8.97 \%$. As compared with December 1996, the interest on 35 day central bank bills was unchanged, while those with a payment date of 91 days were 53 basis points lower than in December 1996.

8 At the current time the interest rate on treasury bills is still somewhat higher than that on central bank bills, although by definition what is concerned are short term securities with the same degree of risk. The reason very likely lies in the different structure of investors and their understanding of conditions on the domestic capital market. Different investor structure is the result of the different purposes of the two money market instruments. Since central bank bills of the CNB are an instrument of monetary control through which free funds are withdrawn from circulation, only the banking sector takes part in the auctions. On the other hand, treasury bills are used to gather funds so as to make the management of the budget more effective, and the non-banking sector can take part 
In comparison with the internal public debt, an attempt to establish the situation and structure of the external public debt gives the concept of "opacity" entirely new dimensions. Monetary statistic have to be used in the absence of systematic and precise statistics from the Ministry of Finance. Relatively precise statistics about the sector structure of domestic debtors abroad have been kept by the CNB since 1996, when questions about shouldering part of the debt of ex-Yugoslavia were settled with the Paris and London clubs, and the linked problem of the inconsistency of the data about the trends and situation of foreign indebtedness. Thus according to CNB statistics, the external public debt at the end of 1996 came to about US $\$ 3.65$ billion. By the end of the next year the foreign debt had risen to about \$US4 billion.?

The fact is that the total indebtedness of the national economy is not simultaneously a direct expression of the public debt stock. But since there is a direct link between the external public and external total debt, the change of the stock of the total indebtedness abroad can in certain situations indicate tendencies in the movements of the national debt. Apart from this, the direct public sector debt is not the only manner in which the state can have an impact on the rise in total indebtedness abroad.

During the period up to 1996, the total foreign debt really can serve as a certain sign about the trends in the Croatian public debt. As can be seen from Table 3, at the end of 1992, the total debt of the Croatian economy abroad was a modest US\$2.69 billion. Four years later, the debt had risen to US $\$ 4.85$ billion, a rise of $80 \%$. If the effects of the reorganisation of the foreign debt in consequence of the agreement reached with the Paris and London clubs are counted in, the debt has to be adjusted by US\$885.2 million. In this case the rise in indebtedness in the four year period from 1992 to 1996 is considerably smaller and comes to $35.6 \%$.

\section{Table 3: Stock of the total foreign debt}

\begin{tabular}{|l|l|r|r|r|r|c|}
\hline (in mil. US\$, end of year) & \multicolumn{1}{|c|}{1992} & \multicolumn{1}{|c|}{1993} & \multicolumn{1}{|c|}{1994} & \multicolumn{1}{c|}{1995} & \multicolumn{1}{c|}{1996} & \multicolumn{1}{c|}{1997} \\
\hline External debt & 2689.7 & 2638.3 & 3066.6 & 3660.9 & 4847.2 & 6130.3 \\
\hline Change & & -51.4 & 428.3 & 594.3 & 1186.3 & 1283.1 \\
\hline Adjusted external debt ${ }^{1)}$ & 3574.9 & 3523.5 & 3951.8 & 4546.1 & 4847.2 & 6130.3 \\
\hline Change & & -51.4 & 428.3 & 594.3 & 301.3 & 1283.1 \\
\hline
\end{tabular}

Source: ***(1996); CNB (1998a).

in the auctions. For this reason the convergence of the interest rates could be referred to the decline in the share of the non-banking sector in the structure of subscribed treasury bills.

9 For the methodology of calculating the foreign public debt according to CNB statistics, see Šonje (1997).

10 Through its fiscal policy, the state can, with the given inclination to save in the private sector, for example by taking up part of domestic savings, encourage the private sector to finance the imbalance between investment and existing savings via foreign debts (Mervar and Mikulić, 1997). Also, giving guarantees to companies that could not borrow abroad without a state guarantee is one of the direct influences on the total foreign debt.

11 In the May number of the CNB Bulletin (1998b) a revision of the foreign debt statistics was done. The total foreign debt in 1997 was US\$531.3 million bigger than the figure shown in Table 3, and according to this, the absolute change in the state of the debt as compared with 1996 comes to US\$1814.4 million. Adjustment was clearly necessary because some recipients of loans did not register their loan arrangements abroad at the CNB in time. At this moment it is difficult to define whether, and to what extent, this increase relates to the state sector. This is a matter mainly of long-term and medium-term loans, and about US\$100 million of short-term loans, almost entirely from foreign banks. For the purposes of this work we shall assume that the state sector registers its foreign loans relatively regularly. 
Note: ${ }^{1)}$ Adjusted to take account of the effects of the Paris and London clubs

In the stock of the debt in 1992 and 1993 "inherited" Croatian debts can be seen. Although it is a matter of Croatian residents - loan recipients, the debt criteria and the way in which the borrowed funds were used were typically "Yugoslav". Because of the troubles Croatia experienced after independence, practically no new loans were taken on abroad up to the end of 1993. Croatian access to the international capital markets became possible only after the successful introduction of the stabilisation programme and the agreement with the IMF, so that financing of reconstruction and economic development started at the end of 1994, or the beginning of 1995 (Babić, 1997).

Since in the agreements with the London and Paris clubs Croatia bound itself to take on the rescheduled debt of the public sector and other sectors, it can be concluded that the stock of the total debt abroad in 1993 was more or less equivalent to the stock of the public debt. It should be stressed that the greater part of the debt assumed from the other sectors should not be a burden on the taxpayer, because although the government took upon itself the obligation to repay debts to foreign creditors, it did not give up its claims against the original domestic debtors. However, creditors abroad are not interested in how and whether the government will manage to collect at home. For them, the debtor is the Republic of Croatia, and we the taxpayers have to hope that in the end the national budget will simply be a neutral channel through which payments abroad are made.

A certain insight into the structure of the external public debt can be obtained from the monthly review of the Ministry of Finance, where the results of Croatia's appearances in the international capital market are regularly shown. Of the foreign credit arrangements, only the syndicated loan of 1996 is mentioned. A much better insight into the structure of the foreign public debt can be obtained from the first annual report of the Ministry of Finance, in which financial relations with certain official creditors (IBRD, EBRD, EIB, CEF) are shown According to the annual report of the Ministry of Finance, the stock with respect to assumed and newly approved loans (funds taken up) from these institutions amounted at the end of 1997 to about US\$450 million. If we add to this the debt to the IMF, the stock of the state debt to international financial organisations came at the end of 1997 to about US\$680 million.

In regulating its obligations to the Paris Club, Croatia assumed the responsibility for repaying US $\$ 1,087$ million to the creditor countries. Rescheduling and refinancing was agreed on for a period of fourteen years. The first annuity of these obligations fell due at the end of January 1998, and payments will be made twice a year. According to the agreement with the creditors of the London Club (commercial banks), a total of US\$1.462 billion in obligations was taken over, and of this US\$857.8 million was exchanged for A Series Republic of Croatia bonds, and the rest for the B Series bonds, which are quoted on the Luxembourg Stock Exchange. 
The agreements with the Paris and London clubs opened wide the doors to international capital markets. Thus between July 1996 when the agreements with the Paris and London clubs were signed and the end of the year, Croatia made its debut in the syndicated loans market and on the Eurobonds market, with its issue of Eurokuna bonds. A loan of DM200 million was agreed upon, with a payment period of two years and a LIBOR DM interest rate increased by 175 basis points. And then, as soon as February 1997, Eurodollar bonds to the value of US\$300 million were issued, maturing in 2002, with an interest rate of 7\%. Five months later Eurobonds denominated in DM in the amount of DM300 million with an interest rate of $6.125 \%$, maturing in 2004 , were issued.

A partial reconstruction of the structure of the external public debt is shown in Table 4 .

Table 4: Structure of the long-term foreign public debt of Croatia at the end of 1997

\begin{tabular}{|l|c|}
\hline & (in mil. US\$) \\
\hline Paris club & 1087.0 \\
London club, A series & 857.8 \\
London club, B series & 570.6 \\
Euro DM & 167.0 \\
Euro USD & 300.0 \\
Syndicated loan & 111.0 \\
International financial institutions (MMF, IBRD, EBRD, EIB, CEF) & 680.0 \\
\hline TOTAL & 3773.4 \\
\hline
\end{tabular}

Source: Ministry of Finance (1998).

Short-term public debt, other loan arrangements of the government with commercial banks apart from the syndicated loan, Eurokuna bonds and borrowings by state agencies (Croatian Bank for Reconstruction and Development - CBRD, for example) are not included in the structure of public debt abroad shown.

\section{The total public debt}

The unanswered questions, crucial if few in number, make a precise purview of the state and structure of the public debt of the Republic of Croatia difficult. This is to do mainly with questions of a methodological nature. First, what should be included in the public debt and second, how much the estimate is under or overrated because of lack of appropriate data. According to Ministry of Finance data (Tables 1 and 4) the stock of the total public debt at the end of 1997 was roughly US\$ 6.075 billion. There are several reasons that lead us to consider this stock of the public debt underrated.

First, according to the last figures of the Finance Ministry, the stock of the internal debt was retrospectively increased by 107.1 million kuna because of a change in the decision about the

12 International Bank for Reconstruction and Development, European Bank for Reconstruction and Development, European Investment Bank, Council of Europe Social Development Fund. 
reconstruction of Riječka banka and Splitska banka 1 Second, it is necessary to take into consideration the facts that the public debt, even in the narrowest sense of the word, must, apart from the debts of the central government, also include those of local government bodies, and that the securities issued by the public sector constitute only one of the instruments of the public debt. Accordingly, the loan arrangements of the central government and local government should be added to the public debt. In a somewhat wider sense, the debts of the extra-budgetary Funds and of the state agencies, and in the widest sense the debts of the public corporations, also represent public debts.

If we confine ourselves to public debt in the narrow sense, then the stock of the internal debt in 1997, of 14,608.7 million kuna, can be increased by the loans received from the banking sector. According to monetary statistics of the $\mathrm{CNB}^{14}$ the stock of kuna loans made to central and local government came (not including the Funds) at the end of 1997 to 297.8 million kuna, and the stock of foreign currency loans was about 691.7 million kuna. So, the adjusted stock of the internal debt (in the narrowest sense of the concept of public debt) at the end of 1997 came to about 15.6 billion kuna. Further, the stock of the external public debt as seen in Table 4 has to be increased by the sum of about US\$109 million, the debt relating to the short-term loan from UBS and the long term credit arrangement with HYPO bank. Accordingly, the external debt comes to more than US\$3.9 billion, which brings us closer to the data from monetary statistics of a public debt of US\$4 billion. 15

If the internal debt came to 15.6 billion kuna, and the external public debt to US\$3.9 billion, the stock of the total public debt of the Republic of Croatia at the end of 1997, not including the debts of the extrabudgetary funds, came to about US\$6.375 billion. This is about 33 percent of GDF of which $20.2 \%$ is accounted for by the external and $12.8 \%$ by the internal debt. Debtors are always optimists, and from this perspective the public debt of the Republic of Croatia is small. As long as foreign creditors think this too, and as long as there is a surplus of capital on the international markets, the state can count on relatively favourable terms for the financing of its deficit abroad.

The fall in the internal debt is accompanied by a simultaneous rise in the external debt. This kind of change in the structure of the public debt points to the policy of refinancing the internal public debt by getting the state into debt abroad. With the growth of the overall budgetary deficit, which is also financed by foreign borrowing, the public sector is absorbing most of the new net borrowings abroad.

13 See: Ministry of Finance (1998c)

14 See Table D5 in the CNB Bulletin

15 According to monetary statistics, obligations relating to Eurokuna bonds issued in the international money market are part of the external public debt. In this work the entire issue of these bonds is classified as internal public debt, because that is how the bonds are presented in the reports of the Ministry of Finance.

16 The internal debt is calculated in terms of dollars according to the midpoint exchange rate of the CNB at the end of the period. These midpoint exchange rates of the $\mathrm{CNB}$ at the end of the period are used in all calculations into and out of DM, US\$ and HRK. According to the CNB Bulletin of June 28, 1997, GDP in current prices amounted to US\$19.322 billion. 
Although not directly a debt, a state guarantee can very soon actually become so and become a burden on the budget and the taxpayer. The usefulness of state guarantees is to be seen in the reduction of the costs of financing for those players in the economy who are able to pay back the debt. Those who cannot pay back, either today or tomorrow, are the chief source of danger that a guarantee will be transformed into an original public debt. Accordingly, the importance of transparent and strict regulation of the issue of guarantees is incontrovertible, and the co-operation of all institutions authorised to issue them.

During 1997, the Croatian government, via the Finance Ministry, issued over seventy state guarantees, in a total amount of about 5.574 billion kuna. Of this almost 53\% comes to performance guarantees in the shipbuilding industry. Over $50 \%$ of the guarantees were issued to foreign creditors, confirming the thesis that most of new indebtedness abroad in 1997 is accounted for by public guarantees and the public debt. State guarantees issued should be an integral part of the public debt statistics, which, separate from the real public debt, should contain a review of all currently valid state guarantees, that is, of a potential public debt. This means that currently valid guarantee contracts from the previous period should be added to guarantees issued in 1997. The amount of currently valid guarantees from the previous year came at the end of 1997 to about 1.903 billion kuna, which makes the total of state guarantees at the end of 1997 close to the sum of 7.5 billion kuna.

The number of state guarantees issued is still growing. The recipients are mostly state owned companies. Considering the recipients, and the rise in the number of currently valid guarantees, the likelihood that some of them might have to be activated is also rising. In fact, from the point of view of the last link in the chain of indebtedness, the taxpayer, it is quite irrelevant whether the state will meet the guarantee or "reconstruct" the debtor. Because sooner or later, the burden is going to fall upon his shoulders.

The chain of indebtedness is as strong as its weakest, and not its strongest link. And whether the decision makers are really thinking through how strong this last link is will be seen in the very near future.

\section{The savings-investment gap}

If the level of national savings is really too low to finance investment then the only alternative is financing from abroad. Foreign savings can be attracted in two ways: through direct foreign investment, or via domestic sectors taking on debts abroad.

\footnotetext{
17 See: Review of guarantees issued in 1996 (Narodne novine Nos. 61/96, 76/96, 2/97). The guarantees started being issued during 1995, and the publication of reviews started in Narodne Novine in 1996. If it is to be assumed that during 1995 some guarantee contracts with a life of more than two years might have been entered into, then the amount of 7.477 billion kuna might seem an understatement.

${ }_{18}$ Portfolio investments also represent one of the ways of attracting foreign savings. However, apart from portfolio investment in a few Croatian blue chip companies of which only Pliva and Zagrebačka banka have been quoted on the international capital market, it is hard to talk of any strategic portfolio investment over the long term. On the other hand, especially in moribund and undeveloped markets like the Croatian capital market, speculative players can more frequently be found. When they arrive in the market, there is a sudden rush of optimism that later
} 
At the beginning of the nineties the wave of direct foreign investment that had been set off passed Croatia by because it was a country of high risk. Since we were not able to provide security for foreign capital until the end of the war, the level of direct foreign investment in Croatia amounted by the end of 1996 to a modest US\$890 million.

Direct investments go hand in hand with portfolio investments, which are in constant search of new emerging markets. The emerging market of the eighties was in Asia, in the nineties the former socialist countries, and by all accounts the next emerging market will be Africa. For this reason today direct foreign investment needs much greater involvement of the state, creating and promoting appropriate institutional advantages. Capital does not move to a country in which institutional and other conditions are the same as at home or worse. The host is the one who has to take the initiative, and the guest will come, and stay, if he feels like it. The interests of host country and the interests of investors can be completely different, but what is essential is a joint interest, that is mutual profitability.

If we put direct foreign investment to one side, there is still the financing of investments by borrowing abroad. If the debts of the private sector are distinguished from those of the public sector, most experts will agree that the state is a relatively poor entrepreneur and according to the criterion of efficiency, public investments cannot stand comparison with the investments of the private sector. In our own history we can find the best arguments to prove this point of view. Since most of the new net borrowings abroad relate precisely to the state and public corporations, we have reason enough for caution. The retreat of the state from the domestic market and its turning to foreign countries is a sign not of the generosity of the government, wishing to avoid crowding out private borrowing, but of a rational decision to look for cheaper financing abroad. And if it is not worth the government's while to borrow even minimally on the domestic market, then it must be equally dubious for a private entrepreneur, whatever business he might be dealing in.

Since the government, by definition, can take on debts under the most favourable conditions, what is worth the while of the government and the entrepreneur is public sector borrowing abroad, the funds then being transferred under the same conditions to new, flexible, productive enterprise. Such a melding of government borrowing with the element of direct private investment ensures, with the minimum effort to the state, the maximum mutual positive result. More favourable conditions of (especially long-term) financing could help a rational domestic entrepreneur to think more of production than of commerce and

sustains domestic investors. After these foreign investors withdraw, there is a bear market, and domestic investors once again find themselves on a dry and non-liquid market. Because of such ebbs and flows in the market, directed from without, at this moment it seems justified to speak only of direct foreign investment and borrowings abroad by domestic sectors as the alternatives to the mobilisation of foreign savings.

19 According to preliminary balance of payments figures of the CNB, direct foreign investment in the period between 1993 and 1996 amounted to US\$814.2 million (CNB, 1998c). According to my own estimate, for the period up to 1993 , direct foreign investment came to about US\$60 million. 
imports, and the state would have a direct benefit from the growth in employment and the taxation base. In any case, a balanced approach between investment in private sector programmes and in infrastructure projects would make Croatia less sensitive to a future possible shortage of capital on world markets. Decision makers have to be aware that the Croatian debt is not like that of the USA, which can be refinanced until the day of judgement and will in essence never fall due, and that such disturbances can, especially for small, open economies, have very serious consequences.

Great changes in the stock of the total indebtedness of the public sector are not very likely while foreign financing of the deficit accompanies a reduction of the debts of the state to domestic creditors. Bearing in mind the savings-investment gap, it is clear that the external public and the total foreign debt will rise. However, a positive impulse to the growth of domestic savings and the creation of an investment culture in Croatia could derive from the domestic market in long-term government securities. One such impulse could be the refinancing of the old debt with new and marketable instruments. From the standpoint of monetary policy, the issue of a new debt and the purchase of the old debt would be a relatively good operation. What is more, there would be greater opportunities for the central bank to use indirect, market mechanisms in carrying out its monetary policies, instead of the policy of the mandatory reserve. The local market for the public debt would certainly gain in terms of liquidity and increased investor confidence and a (future) stable yield curve on the long-term public debt would be the most reliable market signal of whether it pays the country to borrow, and if so where, at home or abroad.

\section{Conclusion}

Since it is difficult to comprehend the public sector, so it is difficult to provide an unambiguous definition of what makes up the public debt of a given country. Depending on the purview of the statistics of the public sector, we can distinguish between public debt in the narrower and in the wider meaning of the word. In a narrow sense, public debt can be defined as every form of indebtedness of central and local government. In a wider sense, apart from this, public debt embraces the debts of the extra-budgetary funds. The debts of public enterprises could also be added to the public debt, as well as those of companies in which the state is the major shareholder.

From the public debt standpoint, the application of the IMF's Government Finance Statistics methodology should make it possible to keep precise track of the stock of the domestic and foreign public debt in Croatia. However, there is a general impression that domestic statistics concerning the public debt lag very much behind other statistics concerning the public sector. From the point of view of the transparency of public finances, it is certain that conditions in other countries in transition are also complex, even much more so than in Croatia. But if the countries of the developed world could be our models, then 
comparisons with the countries of the former eastern bloc do not make much sense. Unless, of course, we are looking for an excuse or, worse still, consolation.

Apart from there being the problem of the correct purview of the state of the total public debt, other methodological failures of adjustment have to be addressed as well. Thus in the monthly statistical reviews of the Ministry of Finance the entire debt arising from the Eurokuna bonds is shown as an internal public debt, which raises questions about the classification criterion. Because if one takes the market on which the loan is raised, then a half of this debt should be classified as external public debt. On the other hand, if one adopts the criterion of the currency in which the debt is denominated, then most of the internal debt denominated in a foreign currency is not actually an internal public debt. If one used the criterion of the residency status of the owners of the public debt, then it would be clear which part of the public debt has the nature of foreign or internal debt. For such a public debt classification, there should be an integrated register of securities at the Finance Ministry including both the non-banking and the banking sectors. If appropriate co-operation with the $\mathrm{CNB}$ were established, it would be possible to estimate what state securities issued in the country 20 are currently in the hands of foreigners, or how many and which securities foreign investors have bought up on the domestic secondary market. When this amount has added to it loan arrangements with foreign countries and supranational financial institutions, the purview of the foreign debt will be complete. Therefore, until the Finance Ministry starts its statistical review with an announcement of the stock and structure of the foreign public debt, the Croatian public will tend to draw a comparison between the stock of the total foreign debt (Table H8 in the CNB Bulletins) and the public debt abroad. And this, we hope, is in nobody's interest.

At this moment, Croatia finds itself in economic conditions such that there are no short-term solutions for them. The consequences of the Serb aggression will be felt for a long time to come, and years will be needed for what has been destroyed to be built up again. Saving is a basic precondition for this. If domestic savings are insufficient for this investment, it is logical to reach out for foreign savings. Foreign savings, however, can easily become a double edged sword, especially if the funds borrowed are not properly invested. And it is a fact that in particular the inherited debt, which represents a serious component of the total indebtedness abroad, was not properly invested.

Since the public sector predominates in total foreign indebtedness, and since the efficiency of public investment is very hard to measure, the effect of the public debt on the economic development of a country is (particularly) questionable. So, when it thinks about whether it will finance its deficit at home or abroad, a responsible government must, apart from its own financial needs, bear in mind the economic effects of getting into debt in the present and the consequences of paying off the debt in the future. It also

20 If foreign investors do not have a direct access to the domestic primary market, this still does not mean that they cannot buy securities on a secondary market. If a security stays abroad until it matures, then irrespective of which currency the security is denominated in, there must be an outflow of funds from the country, so that it is completely justified to talk of a foreign public debt. 
has to be aware that holding out a helping hand to market non-swimmers can also pull the wellintentioned rescuer down to the bottom as well, especially if he overestimates his own capacities.

It is clear that there are many challenges for the small and open Croatian economy at the turn of the millennium. The safest way of foreseeing the future is, as far as is possible, to create the future ourselves. Thus the primary task of (not only) economic policy should be to think up strategies for the future and for the direction of the Croatian ship towards the destination that has been determined. And economic theory and practice both point to the policy of the public debt and its management as being an important part of the navigational instrumentation. Without this, a look into the crystal ball might reveal a picture without a frame and a ship made of paper. 


\section{REFERENCES}

Babić, Ante (1997) Vanjska zaduženost i pokazatelji zaduženosti Republike Hrvatske 1994-1996, Privredna kretanja i ekonomska politika, No. 61, pp. 65-99.

CNB (1998a) CNB Bulletin, No. 26, Zagreb.

CNB (1998b) CNB Bulletin, No. 27, Zagreb.

CNB (1998c) CNB Bulletin, No. 28, Zagreb.

IMF (1992) Summary of Methodology, in A Manual on Government Finance Statistics, Washington D.C: IMF.

Mervar, Andrea i Mikulić, Davor (1997) Projekcija BDP-a, platne bilance i javnog duga Republike Hrvatske do 2010. godine, Privredna kretanja i ekonomska politika, No. 61, pp. 100-130.

Ministry of Finance (1997a) Monthly Statistical Review of the Ministry of Finance, No. 17, Zagreb.

Ministry of Finance (1997b) Monthly Statistical Review of the Ministry of Finance, No. 26, Zagreb.

Ministry of Finance (1998) Annual Report of the Ministry of Finance 1994-1997, Zagreb.

Ministry of Finance (1998a) Monthly Statistical Review of the Ministry of Finance, No. 29, Zagreb.

Ministry of Finance (1998b) Monthly Statistical Review of the Ministry of Finance, No. 30, Zagreb.

Ministry of Finance (1998c) Monthly Statistical Review of the Ministry of Finance, No. 31, Zagreb.

Musgrave, Richard i Peggy (1993) Javne financije u teoriji i praksi, Zagreb: Institut za javne financije.

Prskalo, Nikola (1994) Sanacija i restrukturiranje banaka - jesen zatvara slavine trošenja, Privredni vjesnik, No. 4, pp. 1.

Šonje, Velimir (1997) O statističkim podacima o javnom dugu Republike Hrvatske, Privredna kretanja $i$ ekonomska politika, No. 61, pp. 131-138.

Pregled izdanih jamstava u 1996. godini, Narodne novine Nos.61/96, 76/96, 2/97.

Uredba o izdavanju obveznica za prikupljanje sredstava za obnovu Republike Hrvatske, Narodne novine No. 65/91.

*** (1996) The Republic of Croatia - A Presentation to Standard \& Poor`s on Credit Ratings, November 1996. 